\title{
Electrical Engineering Education for a Sustainable World: Adjustment of Academic Programs in Ecuador
}

\author{
Christopher Reyes-Lopez, M.E. ${ }^{1}$, and José Jaime-Carriel, M.S. ${ }^{1}$ \\ ${ }^{1}$ Universidad Politecnica Salesiana, Ecuador, creyes1@ups.edu.ec, jjaime@ups.edu.ec
}

\begin{abstract}
Electrical engineering has been one of the most evolving fields of the engineering since its origin as a profession in the late nineteenth century. As a result, the program offered by universities has had to face challenges to adapt to an ever-changing environment. This article assesses the impact of the modifications performed in electrical engineering programs of Ecuador to fit in a world that currently focuses on renewable energy and sustainable development while educating future professionals possessing the competences required by the national energy sector. To achieve this goal, the project proposes different evaluation criteria that respond to the three elements of study: educational objectives, curriculum content and learning components. Such criteria include content analysis, online survey and interviews with specialists. The outcomes indicate most universities have updated their curriculum into the current national energy exploitation scene; however, they do not count with the necessary resources to teach specialized courses on energy sustainability.
\end{abstract}

Keywords-curriculum update, energy engineering, higher education, learning activities, undergraduate program.

Resumen-La ingeniería eléctrica ha sido uno de los campos más versátiles de la ingeniería desde su origen como profesión a finales del siglo diecinueve. Como resultado, el programa ofertado ha tenido que enfrentar varios desafios para adaptarse a un ambiente en constante cambio. Este artículo evalúa el impacto de las modificaciones efectuadas en los programas de ingeniería eléctrica en Ecuador para ajustarse a un mundo que actualmente se enfoca en las energías renovables y el desarrollo sostenible, mientras educa a futuros profesionales poseedores de las competencias requeridas por el sector energético nacional. Para alcanzar este objetivo, el proyecto propone diferentes criterios de evaluación que responden a tres elementos de estudio: objetivos educacionales, contenido curricular y componentes de aprendizaje. Tales criterios incluyen análisis de contenido, encuesta en línea y entrevistas a especialistas. Los resultados indican que la mayoría de las universidades han actualizado sus currículums al escenario actual de la explotación energética nacional; sin embargo, no cuentan con los recursos necesarios para impartir cursos especializados en sustentabilidad energética.

Palabras clave- actividades de aprendizaje, actualización curricular, educación superior, ingeniería en energías, programa de pregrado.

\section{INTRODUCTION}

As most countries, Ecuador is keen on exploiting renewable resources and integrating clean energy into its national electric network with the purpose of accomplishing sustainability. To achieve this goal, the Ecuadorian Government executes projects and takes measures that comply with the long-term policies defined in the Master Plan of
Electrification 2013-2022 (MPE) [1]. The MPE is an integral and intersectoral tool promoting the utilization of renewable resources to guarantee the supply of the national energy demand, ensuring appropriate security, reliability and quality levels under technic, economic, social and environmental criteria [2].

The series is divided in four volumes, being the first volume the executive summary, which includes the general objectives of the MPE: (i) to forecast the energy demand, (ii) to build the infrastructure to supply the national capacity, focusing on the renewables, (iii) to strengthen the transmission grid to adapt to future energy needs, (iv) to improve and expand the systems for distribution and commercialization of energy, and (v) to promote the integral growth of all the elements involved in the electricity supply chain.

The second volume presents the forecast of the national electric demand in short, medium and long term, considering the incidence of politic, economic, social, demographic, environment, technic and technologic variables [3]. The third volume shows strategies for expanding the generation, transmission and distribution, aligned with the scope of the national plan of good living and planned to improve the energy matrix [4]. And the fourth volume implements policies and programs focused on efficient energy consumption [5].

Notwithstanding the MPE guidelines, the adoption of renewable energy (RE) has provoked energy companies to face new challenges and requirements, such as engineers who can integrate specific knowledge and expertise of hybrid systems into an efficient electricity network [6]. In this respect, studies confirm that there exist gaps about sustainability in various study plans [7], [8]. Moreover, they demonstrate that student's knowledge of energy engineering mostly depends on the education imparted in the universities, showing significant variations between students from different university [9].

The educational curriculum must face the challenges caused by the needs of an ever-changing world, like technologic and scientific discoveries, needs of the work field, economy fluctuations, social inequalities, intercultural relations, human and environmental rights and, spiritual and ethical values [10]. These challenges must lead to an update of curricula that acknowledges the importance of sustainability and transdisciplinary understanding [11], taking the academic programs towards a globalized education [12].

Some higher education institutes are updating the curricula to promote sustainable development and awareness of climate change [13], [14], while others are even offering new

Digital Object Identifier (DOI):

http://dx.doi.org/10.18687/LACCEI2019.1.1.208

ISBN: 978-0-9993443-6-1 ISSN: 2414-6390

17 $7^{\text {th }}$ LACCEI International Multi-Conference for Engineering, Education, and Technology: "Industry, Innovation, And Infrastructure for Sustainable Cities and Communities", 24-26 July 2019, Jamaica. 
engineering programs [7]. For instance, the Holon Institute of Technology in Israel is introducing the RE program at the Faculty of Electrical Engineering. It provides students with theoretical and practical aspects of energy generation, use and efficiency, but simultaneously it also allows them to understand the policy and environmental impacts [15].

A study takes as starting point the insertion of graduates into competitive engineering fields marked by attributes of sustainability and knowledge sharing to identify appropriate solutions to achieve a sustainable engineering education in universities. It remarks the exploitation of managerial skills, promotion of technological entrepreneurship and analysis of environmental issues in order to prepare students not only to become engineers but also technopreneurs [16].

In addition, [17] demonstrates the vital role of universities to teach engineering students taking basic sciences courses the importance of sustainability through technologic, environmental, ethical, social and economic aspects that favor their professional development and performance complemented with a sustainable culture.

Further, findings indicate that there exists a heightened sense of awareness of environmental, social, economic and cultural dimensions of sustainability among university students [18]. Students believe these topics are necessary for their future profession and that the inclusion of sustainability courses should be helpful to create a complete knowledge of sustainability, but specially to have a real-world learning.

Furthermore, some universities contemplate new approaches to improve education, such as problem-based learning curriculum, thought for the energy engineering students to learn in an integrated and practical fashion, foreseeing the needs of an evolving field. This type of approaches considers different principles of modern education, such as contextual, collaborative and experiential learning [19].

Ecuador acknowledges the importance of sustainability for the country, which led the national entities for regulation and control of higher education to ask the universities for updating the plans of most undergraduate programs. As for the electrical engineering (EE) major, this update includes modifications in the curricula introducing renewable energy, sustainability and sustainable development (RESSD) courses in the programs.

In this context, this paper aims to assess the impact of including RESSD studies in the curriculum of the EE undergraduate programs offered by higher education institutions in Ecuador. It analyzes three academic elements to recognize whether universities are preparing future electrical engineers with specialized technological knowledge of $\mathrm{RE}$ based on the requirements of the national energy market. And consequently, whether such engineers are prepared for the transformation of the energy matrix of Ecuador.

After the introduction, it follows the Materials and Methods section, which presents the elements under study and evaluation planning. Next, the Findings section explains how EE programs in Ecuador are taking part in the education of future employees with up-to-the-date knowledge of renewable energies, energy efficiency and sustainability. Finally, authors discuss the results, propose further studies and conclude the achievement of the objective.

\section{MATERIALS AND METHODS}

Previous works [20], [21] have identified different useful dimensions, such as university capability and student development, to estimate whether undergraduate students truly receive a competitive education. On the one hand, the first dimension comprises the university infrastructure, social responsibility, sustainability, and research, development and innovation $(\mathrm{R} \& \mathrm{D}+\mathrm{i})$. On the other, the second dimension considers the student's development from an individual perspective that includes self-directed, collaborative, contextual and interdisciplinary learning.

Nonetheless, this research suggests the study of an alternative dimension, the academic program itself, as the basis of a valid assessment of the EE education offered by universities. It comprises a set of three elements that were examined via different criteria. Table 1 shows the structure of the evaluation criteria of the academic programs.

TABLE 1

EVALUATION CRITERIA OF THE ELECTRICAL ENGINEERING UNDERGRADUATE CURRICULA (SOURCE: THE AUTHORS)

\begin{tabular}{|c|l|}
\hline Program Evaluation Element & \multicolumn{1}{c|}{ Criterion } \\
\hline \multirow{2}{*}{ Educational objective } & $\begin{array}{l}\text { Aligned with program, needs } \\
\text { of job market and the MPE }\end{array}$ \\
\cline { 2 - 2 } Curriculum content & $\begin{array}{l}\text { Renewable energies and } \\
\text { sustainability courses }\end{array}$ \\
\cline { 2 - 2 } Learning components & $\begin{array}{l}\text { Contextual and experiential } \\
\text { learning }\end{array}$ \\
\hline
\end{tabular}

This research began with a content analysis of the MPE, based on its axes and scopes, to identify the categories of study. Then, a documentary analysis helped find the objective, curriculum and academic requirements of EE undergraduate programs offered in Ecuador as empirical referents [22]. For this reason, the retrieval of input data was compulsory to determine the three evaluation elements.

The first element, the educational objectives were processed through a content analysis to decide whether comply with the overall program structure and the requirements of the current job market [24], as well as the scope and predictions of the MPE. Whereas a comprehensive review of approved academic curricula will permit to filter universities, based on the offer of specialized courses related to RESSD, to find the second element [25].

Later, a survey was conducted to a representative of each EE program in Ecuador in order to find the third element. The questionnaire consists of fifteen questions, and it intends to evaluate the department's readiness to teach RESSD courses and the strategies applied to optimize the applicability of

$17^{\text {th }}$ LACCEI International Multi-Conference for Engineering, Education, and Technology: "Industry, Innovation, And Infrastructure for Sustainable Cities and Communities", 24-26 July 2019, Jamaica. 
learning components in the program. It means, the element 'learning components' does not evaluate the conventional classroom schooling. Instead, it assesses tactics to dynamically improve the student's performance.

In this framework, the strategies of the learning components regard mainly contextual and experiential learning. The first facilitates student's learning through the use of design thinking, project-based and maker-based activities [29]. The second involves student into industry projects to develop professional skills [30].

According to the Council for the Evaluation Accreditation and Quality Assurance of Higher Education [23], Ecuador counts 55 institutions classified based on academic quality standards into category A (8 universities), category B (28), and category C (19). Whereof eleven offer EE programs but only ten were considered because of their participation in the survey and the program-related information available online.

It was found important to contrast national EE programs with an internationally renowned counterpart. The electrical engineering and computer science (EECS) program at MIT [26] has repeatedly been ranked number one for undergraduate engineering programs in the USA [27]. Moreover, the [28] positioned it third for EE programs in the world. Given that background, MIT EECS was used as the comparison reference.

Finally, a group of EE experts was consulted about the expected competences for an entry-level job at the companies where they work at. Two international researchers were consulted about EE education as well. This short series of interviews will add different perspectives to the study and help confirm or deny the results through triangulation.

\section{RESULTS}

\section{A. Educational objective}

After CEAACES appraised each EE academic program, the need for aligning the educational objective with the program scope and the trends in energy market appeared. The content analysis of the first evaluation criterion is vital to determine if the programs aim at complying with the guidelines of the MPE, especially those concerning RESSD. To achieve the conceptual analysis, several recording units represent each category [31].

Six categories related to RESSD were defined after reading the MPE: renewable energy, economic conscience, environmental responsibility, social sense, knowledge sharing (R\&D+i) and country development. Table 2 presents the analysis of the educational objective and graduate profile of the ten universities based on the occurrence of the recording units in each document.

Only one university states the six categories in the program scope and graduate profile, while 4.5 is the average number of categories identified among all universities. Three categories, social conscience, knowledge sharing and country development, are the most present, with an occurrence of nine out of the ten universities.

As defined in the methodology section, the educational objective will be contrasted to the MIT EECS program objective, which states that its graduates:

"approach new problems with a technical orientation, whether these problems involve engineering, management, medicine, education, law, or the creative arts",

TABLE 2

CONTENT ANALYSIS OF PROGRAM OBJECTIVES AND GRADUATE PROFILE PER UNIVERSITY (SOURCE: THE AUTHORS).

\begin{tabular}{|c|c|c|c|c|c|c|}
\hline Item & $\begin{array}{l}\text { Renewable } \\
\text { energy }\end{array}$ & $\begin{array}{l}\text { Economic } \\
\text { conscience }\end{array}$ & $\begin{array}{c}\text { Environmental } \\
\text { responsibility }\end{array}$ & Social sense & $\begin{array}{l}\text { Knowledge } \\
\text { sharing }\end{array}$ & $\begin{array}{c}\text { Country } \\
\text { development }\end{array}$ \\
\hline $\mathrm{U} 1{ }^{\mathrm{A}, \mathrm{S}}$ & $\mathrm{X}$ & $\mathrm{X}$ & $\mathrm{X}$ & $\mathrm{X}$ & $\mathrm{X}$ & $\mathrm{X}$ \\
\hline $\mathrm{U} 2{ }^{\mathrm{A}, \mathrm{S}}$ & - & $\mathrm{X}$ & $\mathrm{X}$ & $\mathrm{X}$ & $\mathrm{X}$ & $X$ \\
\hline $\mathrm{U} 3^{\mathrm{A}, \mathrm{s}}$ & - & $\mathrm{X}$ & - & $X$ & $\mathrm{X}$ & $\mathrm{X}$ \\
\hline $\mathrm{U} 4^{\mathrm{B}, \mathrm{P}}$ & $\mathrm{X}$ & - & - & $\mathrm{X}$ & $\mathrm{X}$ & $\mathrm{X}$ \\
\hline $\mathrm{U} 5^{\mathrm{B}, \mathrm{P}}$ & $\mathrm{X}$ & - & $\mathrm{X}$ & $\mathrm{X}$ & $\mathrm{X}$ & - \\
\hline $\mathrm{U} 6^{\mathrm{B}, \mathrm{S}}$ & - & $\mathrm{X}$ & $\mathrm{X}$ & $\mathrm{X}$ & $\mathrm{X}$ & $\mathrm{X}$ \\
\hline $\mathrm{U} 7^{\mathrm{C}, \mathrm{s}}$ & - & $X$ & $X$ & $X$ & $\mathrm{X}$ & $\mathrm{X}$ \\
\hline $\mathrm{U} 8^{\mathrm{B}, \mathrm{P}}$ & - & X & X & - & - & $\mathrm{X}$ \\
\hline U9 ${ }^{\mathrm{c}, \mathrm{s}}$ & - & $X$ & - & $\mathrm{X}$ & $\mathrm{X}$ & $\mathrm{X}$ \\
\hline $\mathrm{U} 10^{\mathrm{C}, \mathrm{P}}$ & - & $\mathrm{X}$ & $\mathrm{X}$ & $\mathrm{X}$ & $\mathrm{X}$ & $\mathrm{X}$ \\
\hline
\end{tabular}

$17^{\text {th }}$ LACCEI International Multi-Conference for Engineering, Education, and Technology: "Industry, Innovation, And Infrastructure for Sustainable Cities and Communities", 24-26 July 2019, Jamaica. 
"will bring to their careers the self-assurance, integrity, and technical strengths that drive

student pursuing a bachelor's degree to complete hours of internship and community service before thesis defense.

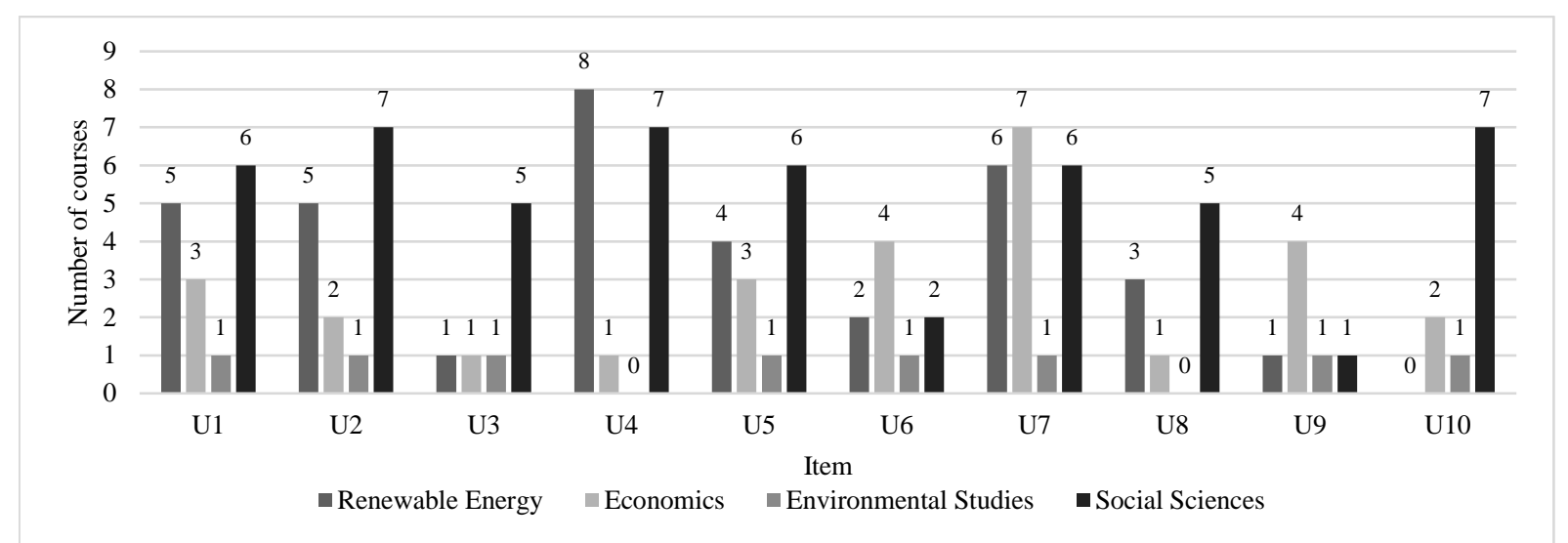

Fig. 1 Number of courses related to RESSD per university (Source: The authors).

innovation, and the communication and collaboration skills to inspire and guide the groups they work with in bringing their ideas to fruition.", "will apply their abilities, talents, and insights creatively and productively in fields and professions beyond those explicitly represented in, or anticipated by, the EECS curriculum.", and

"will be sensitive to professional and societal contexts, committed to ethical action, and engaged in life-long learning to remain effective members of their communities." [32].

Categories RE and Environmental responsibility were not overtly identified from the previous excerpts as the other four were. As seen previously, most Ecuadorian programs does not specify those two categories either. It allows to infer that these categories are implicitly considered covered by EE programs since RE is already a form of energy generation and environmental responsibility is mandatory for utilities companies.

Nevertheless, the EECS objective exposes its interest in interdisciplinary and even transdisciplinary education. It may also be easily interpreted that MIT promotes creativity, communication, collaboration, ethics and life-long learning skills. It would seem that MIT exploits its students' maximum potential to almost commit them to success in life.

\section{B. Curriculum content}

Ecuadorian programs give scarce possibilities of selecting courses different of those indicated in its rigid curriculum. Thereupon, curriculum content becomes an important factor to appraise the education imparted to the students. This second element does not appraise the last two categories, since universities are cradles of knowledge with the purpose of sharing it with the public to support the progress and well-being of the nations. Moreover, Ecuadorian regulation requires each
Instead of examining the core courses, such as machinery and power systems, the main target of this review includes: (i) RE courses, such as alternative energies, energy conversion and hybrid systems; (ii) economics courses, such as finance engineering and project management; (iii) environmental courses, such as ecology and environmental education; and (iv) any other social sciences and arts courses. Figure 1 compiles the number of courses organized by category, taught at each program.

Most universities have bet for the introduction of RE courses in the curriculum. An average of 3.5 courses per program shows the interest in this branch of EE. A program reaches eight energy-related courses, while other offers none. The economics is other field identified as important in undergraduates' education. For this reason, all the programs include at least one of these courses, while 2.8 is the average number. Some programs even offer economy-related courses for the engineer's education, including technological entrepreneurship and innovation.

Concerning environmental studies, EE programs consider them as the less related to power engineering. This is demonstrated by a maximum of one course per curriculum, and two curricula containing none. Contrarily, the highest number of imparted courses corresponds to the socials, with an average of 5.2. These belong to varied fields though, ranging from laws to fine art courses.

The EECS curriculum varies largely in depth, hands-on courses and spectrum of approaches compared with the Ecuadorians. It demands undergraduates to take courses related to basic sciences, core technologies, advanced math, programing, laboratories, as well as foundation, header, specialization and advanced subjects. However, it emphasizes the importance of alternative courses in the development of electrical engineers.

The distribution of subjects, out of the EE basic and core courses, differs to the categories before defined. The alternative paths focus on Science and Technology (2 courses),

$17^{\text {th }}$ LACCEI International Multi-Conference for Engineering, Education, and Technology: "Industry, Innovation, And Infrastructure for Sustainable Cities and Communities", 24-26 July 2019, Jamaica. 
Humanities, Arts and Social Sciences (8), Research or facilitation (1), Innovation initiative (1), Development (1), Communication skills (1), and Physical education (1). It might be concluded that MIT bets, not only on teaching conventional topics, but on developing undergraduate's skills and capabilities.

The energy minor is available for students who want to pursue a RE specialization or take some of its courses [33]. Regarding environmental sciences, such elective courses are in the list of Science and technology, so students are not obliged to, but they may take them.

Knowledge sharing and country development are not appraised for the same reasons as in the findings per university. It may be mentioned that MIT offers other opportunities, such as research, internships and social service programs. However, they are not imposed as a requirement to be granted the bachelor's degree, as it does occur in Ecuador.

\section{Learning Components}

The third evaluation criterion intends to get direct answers from a representative of the Department of Electrical Engineering of each university. Hence, the short questionnaire responding to the six categories was directly emailed to them.

Regarding the category RE, the responses states a lack of technological resources and low percentage of lecturer with the appropriate profile. It means, the country is not yet prepared to offer RE courses.

Although the universities promote the active participation of students in projects on economic, environmental and social development, the percentage of faculty capable of teaching sustainability-related courses in the program is in average very low, much lower than for RE obviously.

Concerning knowledge sharing, most Ecuadorian universities are introducing alternative learning methodologies, including talks with experienced professionals and field trips. Additionally, lecturers are constantly sharing and widening their knowledge in events that get academia and industry together, as well as involving students in academic research.

The adoption of the MPE guidelines during the curricular modifications demonstrates the compliance with the final category 'country development' because the programs try to fulfill the national energy requirements. Moreover, the participation of students in real life projects through agreements between universities and energy companies and regulators reflect a mutual disposition to contribute in local and national projects for country development.

\section{Series of interviews}

Eight professionals working in energy companies and regulator entities were consulted to know, in some measure, the basic competences a graduate should hold for an entry-level job at their employers, and if knowledge of renewable energy is required. Two from the Electric Corporation of Ecuador (Hidropaute and Hidronacion), one from the National Electricity Corporation, one from the Agency for Regulation and Control of Electricity, one from the Ministry of Electricity and Renewable Energy, and three from private companies.

Concerning the interviewees working in the industry, those working at the public electricity corporations mentioned that a deeper preparation on electrical grid power systems, hydraulic power plants and heavy machinery is needed; whereas those working in private companies referred to automation, motors, generators and transformers, and only one stated that solar power projects appear sporadically.

About those working at the regulators, they spoke of electrical grid power systems and electrical safety but emphasized the high use of statistics and economics in their quotidian tasks. They also pointed out that a scarce knowledge of RE is useful for auditing; however, suggested to include RE subjects because of the new national projects, including wind farms, solar parks and proposals of geothermal energy.

The responses about technical knowledge were too wide and very biased because the needs of each employer can be very different. Nonetheless, regarding personality traits, all interviewees acknowledged the importance of exploiting students' project management, communication, self-learning and teamwork skills in the classrooms.

Additionally, a researcher from the City College of New York and another from the University of the Basque Country were consulted about EE education and the inclusion of RE studies. They agreed on the significance of using highlyequipped laboratories and the integration of contextual and experiential learnings to maximize the students' learning process. For instance, capstone projects allow students to apply what they have learned in class to solve current industry problems, sometimes even in real companies.

Both researchers do not believe recommendable to introduce RE specialized courses because of the scope of the program and the wide range of topics to be taught. Nowadays, leading universities are offering energy undergraduate programs, as well as minors and graduate programs on RESSD, where EE students may specialize their knowledge.

\section{DISCUSSIONS}

The first two elements demonstrate that the effort made, and strategies taken by most Ecuadorian universities have been an attempt to copy international educational trends, when all modifications should focus on developing student's aptitudes and competences. Universities should consider better approaches and courses related to leadership, engagement, creativity and versatility, that will help students succeed in their careers.

The third element exposes that, despite all the knowledge that a higher education institution wanted to impart to its students, too many broad topics will lead to a low engineers' preparation. Leading universities usually overcome such challenge through the introduction of new programs with a high level of specialization, a reduced scope and based on real market studies. Undergraduate programs, or minor 
concentrations otherwise, in RESSD would solve the issue and increase the academic offer of universities.

The three elements expose the need to introduce new technologies and environments dedicated to open and flexible educational proposals, such as virtual and learning-by-doing courses. The need to be part of the knowledge society might be solved through the economic grants the Ecuadorian Secretariat of Higher Education, Science, Technology and Innovation [34] is giving out for research projects. Consequently, this enrichment of education will help prepare engineers not only concerned about fulfilling national and regional energy requirements, but participative in overcoming environmental, social, and economic challenges, from a local to a global context [8], [35].

It is important to remark that Ecuador is recognized as a megadiverse country by the United Nations Environment Programme [36], i.e. one out of 17 countries harboring most of Earth's species and high numbers of endemic species. To home such wide spectrum of diversity, the country consists of diverse landscapes with their own particularities. Thus, each university has considered its own territorial necessities to restructure the electrical engineering program taking advantage of the local natural resources. For this reason, the findings varied from university to university. Moreover, the contrast performed with the MIT EECS does not consider that Ecuador experience a completely different reality compared to Massachusetts or the USA.

This research focused on the dimension of study "Academic Program" to assess the impact of introducing renewable energy studies in the electrical engineering programs. Nevertheless, there exist other dimensions of studies, proposed by different authors, which would help conduct a parallel assessment. Future studies might compare such dimensions with that proposed in this study.

\section{CONCLUSION}

The evaluation criteria suggested allowed to assess the changes appropriated by different EE programs of Ecuador to comply with the requirements of a world in constant evolution that has focused on RESSD since late 1980s. Nonetheless, the results demonstrate that the three elements of study have not been fully accomplished. Therefore, it is compulsory to take further action; such as qualifying lecturers in RESSD, implementing teaching strategies and developing courses that incorporate contextual and experiential learnings. Ergo, it would help stop the existing deficiency in energy engineering education and provide future engineers with crucial skills to support not only Ecuador's energy matrix transformation, but regional and global industries as well.

\section{REFERENCES}

[1] J. Lata-García, C. Reyes-Lopez, and F. Jurado, "Attaining the Energy Sustainability: Analysis of the Ecuadorian Strategy Ku zrównoważoności energetycznej: analiza Strategii Ekwadorskiej," Probl. ekorozwoju / Probl. Sustain. Dev., vol. 13, no. 1, pp. 21-29,
2018.

[2] Ministry of Electricity and Renewable Energy, "Executive Summary," Quito, 1, 2013.

[3] Ministry of Electricity and Renewable Energy, "Study and Management of the Power Demand," Quito, 2, 2013.

[4] Ministry of Electricity and Renewable Energy, "Perspective y Expansion of the Ecuadorian Power System," Quito, 3, 2013.

[5] Ministry of Electricity and Renewable Energy, "Aspects of Sustainability and Social and Environmental Sustainability," Quito, 4, 2013.

[6] M. C. Felgueiras, J. S. Rocha, and N. Caetano, "Engineering education towards sustainability," Energy Procedia, vol. 136, pp. 414-417, 2017.

[7] F. J. Lozano and R. Lozano, "Developing the curriculum for a new Bachelor's degree in Engineering for Sustainable Development," $J$. Clean. Prod., vol. 64, pp. 136-146, 2014.

[8] M. Thürer, I. Tomašević, M. Stevenson, T. Qu, and D. Huisingh, “A Systematic Review of the Literature on Integrating Sustainability into Engineering Curricula," J. Clean. Prod., vol. 181, pp. 608-617, 2017.

[9] J. O. Jaber et al., "Renewable energy education in faculties of engineering in Jordan: Relationship between demographics and level of knowledge of senior students'," Renew. Sustain. Energy Rev., vol. 73, no. February 2016, pp. 452-459, 2017.

[10] M. Ranai, P. Rezai, F. Karimyan, and F. Karimi, "Challenges Rooted in Curriculum Globalization," Procedia - Soc. Behav. Sci., vol. 46, pp. 4567-4570, 2012.

[11] M. Hammer and T. Söderqvist, "Enhancing transdisciplinary dialogue in curricula development," Ecol. Econ., vol. 38, no. 1, pp. $1-5,2001$.

[12] Y. Zhao, "Globalization in Education," in International Encyclopedia of the Social \& Behavioral Sciences, Second Edi., vol. 10, Elsevier, 2015, pp. 247-253.

[13] R. Lozano, "Diffusion of sustainable development in universities' curricula: an empirical example from Cardiff University," J. Clean. Prod., vol. 18, no. 7, pp. 637-644, 2010.

[14] J. Padgham, H. Virji, and C. Seipt, "Promoting climate change curricula development in African universities," Environ. Dev., vol. 5, no. 1, pp. 169-171, 2013.

[15] H. Friman, "New Trends in the Higher Education: Renewable Energy at the Faculty of Electrical Engineering," Energy Procedia, vol. 115, pp. 18-28, 2017.

[16] D. C. Momete, "Promoting Technological Entrepreneurship through Sustainable Engineering Education," Procedia Technol., vol. 22, pp. 1129-1134, 2016.

[17] F. O. Machín Armas, S. G. Céspedes Montano, A. N. Riverón Mena, and E. Fernández Santiesteban, "Sostenibilidad, ingeniería y enseñanza de las ciencias básicas . Marco teórico conceptual," Rev. Iberoam. Educ., vol. 73, pp. 179-202, 2017.

[18] S. Sivapalan, "Sustainability, blended learning and the undergraduate communication skills classroom: negotiating engineering undergraduates' expectations and perceptions," Horiz., vol. 25 , no. 1, pp. 7-23, 2017.

[19] A. Guerra, "Integration of sustainability in engineering education," Int. J. Sustain. High. Educ., vol. 18, no. 3, pp. 436-454, 2017.

[20] J. K. Staniškis and E. Katiliute, "Complex evaluation of sustainability in engineering education: Case \& analysis," J. Clean. Prod., vol. 120, pp. 13-20, 2016.

[21] T. Stough, K. Ceulemans, W. Lambrechts, and V. Cappuyns, "Assessing sustainability in higher education curricula: A critical reflection on validity issues," J. Clean. Prod., vol. 172, pp. 44564466, 2018.

[22] V. A. L. Hernandez and E. L. Villaseñor, "Curricular Innovation and Emerging Knowledge in Chemical Engineering in Mexico. Study Comparative," Procedia - Soc. Behav. Sci., vol. 174, pp. 3374-3377, 2015.

[23] Council for the Evaluation Accreditation and Quality Assurance of Higher Education of Ecuador, "Results of the current accreditation and categorization," CEAACES, 2016. [Online]. Available:

$17^{\text {th }}$ LACCEI International Multi-Conference for Engineering, Education, and Technology: "Industry, Innovation, And Infrastructure for Sustainable Cities and Communities", 24-26 July 2019, Jamaica. 
http://www.ceaaces.gob.ec/sitio/acreditacion-y-categorizacion/.

[Accessed: 27-Oct-2017].

[24] C. Eggenberger, M. Rinawi, and U. Backes-Gellner, "Occupational specificity: A new measurement based on training curricula and its effect on labor market outcomes," Labour Econ., vol. 51, no. July 2016, pp. 97-107, 2018.

[25] A. A. Alawin et al., "Renewable energy education in engineering schools in Jordan: Existing courses and level of awareness of senior students," Renew. Sustain. Energy Rev., vol. 65, pp. 308-318, 2016.

[26] Massachusetts Institute of Technology, "6-1. Electrical Science and Engineering," Degree Requirements for 6-1, 6-2, 6-3, 6-7, and 6-14, 2016. [Online]. Available: https://www.eecs.mit.edu/curriculum2016. [Accessed: 02-Feb2018].

[27] U.S. News, "Best Colleges Ranking," Best Colleges - U.S. News Rankings, 2018. [Online]. Available: https://www.usnews.com/bestcolleges/mit-2178/overall-rankings.

[28] Academic Ranking of World Universities, "Global Ranking on Electrical \& Electronic Engineering 2017," ShanghaiRanking's Global Ranking of Academic Subjects 2017 - Electrical \& Electronic Engineering, 2018. [Online]. Available: http://shanghairanking.com/Shanghairanking-SubjectRankings/electrical-electronic-engineering.html.

[29] M. Ďurišová, A. Kucharčíková, and E. Tokarčíková, "ScienceDirect Assessment of higher education teaching outcomes (Quality of higher education)," Procedia-Social Behav. Sci., vol. 174, pp. 2497-2502, 2015.

[30] T. White, L. D. Scott Jr, and M. R. Munson, "Extracurricular activity participation and educational outcomes among older youth transitioning from foster care," Child. Youth Serv. Rev., vol. 85, pp. $1-8,2018$.

[31] M. Bengtsson, "How to plan and perform a qualitative study using content analysis," NursingPlus Open, vol. 2, pp. 8-14, 2016.

[32] Massachusetts Institute of Technology, "Program objectives," MIT EECS, 2017. [Online]. Available:

https://www.eecs.mit.edu/academics-admissions/programobjectives. [Accessed: 02-Feb-2018].

[33] Massachusetts Institute of Technology, "Energy Science Minor," MIT Energy Initiative, 2016. [Online]. Available:

http://energy.mit.edu/minor/\#requirements.

[34] T. and I. The Secretariat of Higher Education, Science, "Becas Ensamble," Programa de Becas, 2017. [Online]. Available: http://programasbecas.educacionsuperior.gob.ec/becas-ensamble/.

[35] M. J. Durib, "Challenges of Globalization to School Curricula from the Point of View of Faculty Members with Suggestions of How to Deal with it," Procedia - Soc. Behav. Sci., vol. 112, no. Iceepsy 2013, pp. 1196-1206, 2014.

[36] Biodiversity A-Z, "Megadiverse Countries," AREAS OF BIODIVERSITY IMPORTANCE, 2014. [Online]. Available: http://www.biodiversitya-z.org/content/megadiverse-countries. [Accessed: 02-Feb-2018].

$17^{\text {th }}$ LACCEI International Multi-Conference for Engineering, Education, and Technology: "Industry, Innovation, And Infrastructure for Sustainable Cities and Communities", 24-26 July 2019, Jamaica. 